УДК 342.9

DOI https://doi.org/10.32849/2663-5313/2020.4.22

Василь Безега,

ад'юнкт кафедри публічного управління та адміністрування

Національної академії внутрішніх справ

\title{
ПРІОРИТЕТНІ НАПРЯМИ ЗАБЕЗПЕЧЕННЯ ФУНКЦІОНУВАННЯ СЕКТОРУ БЕЗПЕКИ Й ОБОРОНИ ОРГАНАМИ ТА ПІДРОЗДІЛАМИ НАЦІОНАЛЬНОЇ ПОЛІЦЇ
}

Метою статті є визначення та характеристика пріоритетних напрямів забезпечення функиіонування сектору безпеки і оборони органами і підрозділами Національної поліиії. У статті з'ясовано, що основні напрями забезпечення функціонування сектору безпеки і оборони органами та підрозділами Національної поліиії базуються на відповідних завданнях вказаного сектору. Виокремлено та проаналізовано ключові напрями забезпечення функціонування сектору безпеки і оборони органами та підрозділами Начіональної полічіі: боротьба з організованою злочинністю та протидія корупиіï; боротьба з тероризмом; протидія незаконній міграиї та торгівлі людьми; протидія наркоманії, алкоголізму та дитячій безпритульності; забезпечення територіальної безпеки. Наголошено, що під напрямами забезпечення функиіонування сектору безпеки і оборони органами і підрозділами Національної поліиії пропонується розуміти систему пріоритетних завдань та функцій Національної поліиії у сфері охорони начіональної безпеки. Визначено, що забезпечення функиіонування сектору безпеки і оборони органами і підрозділами Наиіональної поліиії - ие законодавчо встановлений комплекс заходів правового, організаційного та фінансового характеру, який спрямований на виконання завдань та функиій щодо захисту державного суверенітету, територіальної иілісності і демократичного конституиійного ладу та інших життєво важливих національних інтересів від реальних i потениійних загроз невоєнного характеру органами та підрозділами Національної поліиії. Серед основних напрямів здійснення територіальної оборони, які забезпечує поліиія, можна виділити: посилення охорони громадського порядку та безпеки громадян; підготовка до боротьби з диверсійно-розвідувальними силами, іншими озброєними формуваннями, антидержавними незаконно утвореними озброєними формуваннями та мародерами; завчасна підготовка у мирний час до охорони та оборони в особливий період важливих об'єктів і комунікачій життєдіяльності; підтримання правового режиму воєнного стану; забезпечення взаємодії суб'єктів територіальної оборони.

Ключові слова: Національна поліція, сектор безпеки і оборони, напрями, завдання, взаємодія.

Постановка проблеми. Незважаючи на вжиті останнім часом заходи, проблема ефективного функціонування сектору безпеки та оборони вийшла на перший план і потребує негайного вирішення. Нинішній стан речей може призвести до катастрофічних наслідків, таких як послаблення економіки і підрив суспільно-політичної стабільності, застосування воєнної сили, а також технологій гібридної війни. Грунтовне висвітлення різних аспектів організації діяльності Національної поліції як суб'єкта сектору безпеки і оборони дало змогу вказати на її важливість, високий рівень впливу на забезпечення національної безпеки загалом. Для визначення основних напрямів забезпечення функціонування сектору безпеки і оборони органами і підрозділами поліції потрібно чітке розуміння усього переліку суб'єктів цього сектору і, відповідно, їхніх функцій.

\begin{abstract}
Метою статті є визначення та характеристика пріоритетних напрямів забезпечення функціонування сектору безпеки і оборони органами і підрозділами Національної поліції.
\end{abstract}

Виклад основного матеріалу. Законом України «Про національну безпеку України» від 21 червня 2018 р. № 2469-VIII визначено, що сектор безпеки і оборони України складається 3 чотирьох взаємопов'язаних складників: сили безпеки; сили оборони; оборонно-промисловий комплекс; громадяни та громадські об'єднання, які добровільно беруть участь у забезпеченні національної безпеки. Функції та повноваження складників сектору безпеки і оборони визначаються законодавством України. До складу сектору безпеки і оборони входять: Міністерство оборони України, Збройні Сили України, 
Державна спеціальна служба транспорту, Міністерство внутрішніх справ України, Національна гвардія України, Національна поліція України, Державна прикордонна служба України, Державна міграційна служба України, Державна служба України 3 надзвичайних ситуацій, Служба безпеки України, Управління державної охорони України, Державна служба спеціального зв'язку та захисту інформації України, Апарат Ради національної безпеки і оборони України, розвідувальні органи України, центральний орган виконавчої влади, що забезпечує формування та реалізує державну військово-промислову політику [1]

Указ Президента України від 14 березня 2016 року № 92/2016 «Про рішення Ради національної безпеки і оборони України від 4 березня 2016 року "Про Концепцію розвитку сектору безпеки і оборони України”» розширює перелік суб'єктів, додаючи до структури Президента України Раду національної безпеки і оборони України та інші складники, що визначені законами України. Окремо Радою національної безпеки і оборони України передбачено створення умов для широкого залучення недержавних організацій до виконання завдань в інтересах національної безпеки і оборони держави. Найбільш перспективними напрямами такої їхньої діяльності мають бути: надання послуг в інтересах виконання миротворчих завдань Збройними Силами України; функціонування мережі недержавних дослідних інституцій, що фахово опікуються проблемами безпеки та оборони [2].

У зв'язку з великою чисельністю державних органів та інших суб'єктів, які входять до сектору безпеки і оборони, доцільно аналізувати основні напрямки забезпечення його функціонування органами i підрозділами Національної поліції за відповідними загрозами національній безпеці.

Загалом, термін «функціонування» означає виконання суб'єктом своїх функцій, під якими розуміють конкретні напрями діяльності, безпосередні дії, що виконуються тим чи іншим елементом системи в $11 ̈$ успішному функціонуванні як цілого [3, с. 107-108].

В. Б. Авер'янов наголошує, що під функціями органів виконавчої влади слід розуміти відносно самостійні та якісно однорідні складники діяльності цих органів, які характеризуються цільовою спрямованістю [4, c. $257-258]$.

О. М. Бандурка зазначає, що саме виконання юридично визначених завдань і функцій є основним показником якості й ефективності діяльності суб'єкта управління $[5$, c. 64$]$.
В. А. Троян у своєму дослідженні підводить підсумок, що більшість учених підтримує тезу, що під функціями органу публічної адміністрації слід розуміти основні напрями його діяльності, в яких відображено його сутність і призначення в державі та суспільстві в цілому [6, с. 15]. Також автор аналізує спроби різних науковців класифікували функції Національної поліції.

Предметом даного дослідження $€$ напрями забезпечення функціонування сектору безпеки і оборони. Розгляд основних напрямів забезпечення функціонування сектору безпеки і оборони органами та підрозділами Національної поліції потрібно розпочати із зазначення завдання вказаного сектору.

До них віднесено:

- оборону України, захист іï державного суверенітету, територіальної цілісності і недоторканності;

- захист державного кордону України;

- захист конституційного ладу, економічного, науково-технічного і оборонного потенціалу України, законних інтересів держави та прав громадян від розвідувально-підривної діяльності іноземних спеціальних служб, посягань з боку окремих організацій, груп та осіб, а також забезпечення громадської безпеки та охорони державної таємниці, іншої інформації з обмеженим доступом;

- попередження, виявлення, припинення та розкриття злочинів проти миру і безпеки людства, інших протиправних дій, які безпосередньо створюють загрозу життєво важливим інтересам України, боротьба 3 тероризмом, корупцією та організованою злочинністю у сфері управління і економіки;

- забезпечення інформаційної та кібербезпеки;

- надання допомоги органам виконавчої влади та органам місцевого самоврядування у запобіганні та ліквідації наслідків надзвичайних ситуацій природного та техногенного характеру, а також воєнного характеру, розвиток міжнародного співробітництва у цій сфері;

- участь у забезпеченні міжнародної стабільності та безпеки [2].

Як слушно зауважує В .Н. Амєльчакова, національна безпека, з одного боку, виступає основою функціонування органів влади, а 3 іншого боку, вона виникає й існує там і тоді, де і коли державна влада в ній зацікавлена. Саме державна влада встановлює і підтримує національну безпеку, охороняє її від порушень, а в необхідних випадках і захищає. У зв'язку з цим, попри всю корисність та продуктивність традиційних для адміністративного права досліджень проблем національної 
безпеки, нині гостро відчувається необхідність системних за своїм характером і комплексних за змістом міждисциплінарних досліджень широкого комплексу проблем, що стосуються адміністративно-правового осмислення питань формування, підтримки та зміцнення національної безпеки [7, c. 5].

Національна поліція України як центральний орган виконавчої влади служить суспільству шляхом забезпечення охорони прав і свобод людини, протидії злочинності, підтримання публічної безпеки і порядку. Ї̈̈ головними завданнями є надання поліцейських послуг у сферах: забезпечення публічної безпеки і порядку; охорони прав і свобод людини, а також інтересів суспільства і держави; протидії злочинності; надання в межах, визначених законом, послуг з допомоги особам, які з особистих, економічних, соціальних причин або внаслідок надзвичайних ситуацій потребують такої допомоги [8; 9, с. 206].

Додатково потрібно вказати на відповідні напрями розвитку сектору безпеки і оборони, які закріплені в Указі Президента України від 14 березня 2016 року № 92/2016 «Про рішення Ради національної безпекиіоборони Українивід4березня2016року "Про Концепцію розвитку сектору безпеки і оборони України” . Для ефективного розвитку сектору безпеки і оборони в сучасних умовах передбачається:

- централізація управління сектором безпеки і оборони у мирний час, у кризових ситуаціях, що загрожують національній безпеці, та в особливий період, підвищення рівня міжвідомчої координації і взаємодії;

- запровадження інтегрованої системи освіти, бойової і спеціальної підготовки персоналу у секторі безпеки і оборони із залученням викладачів, інструкторів із держав-членів НАТО і СС, формування нової культури безпеки зі збереженням за необхідності спеціалізації та індивідуалізації системи підготовки кадрів;

- підвищення фахового рівня персоналу сектору безпеки i оборони, забезпечення його високої мотивації до належного виконання завдань за призначенням;

- забезпечення розвитку системи військово-патріотичного виховання, запровадження програм військової підготовки і цивільного захисту в загальноосвітніх, професійно-технічних навчальних закладах [2].

Розпочинаючи аналіз основних напрямів забезпечення функціонування сектору безпеки і оборони органами та підрозділами Національної поліції, потрібно погодитися 3 тезою А. В. Галюка, що сучасний розвиток суспільного життя характеризується багатьма негативними явищами: це війна на сході нашої держави, економічний спад, низькі соціальні стандарти життя населення, тотальна корупція в органах державної влади, психологічна напруга в суспільстві, високій рівень злочинності [10, с. 40].

В. А. Троян обгрунтовує створення поліції саме як публічно-сервісної служби, що відображає прагнення влади змусити правоохоронну систему служити інтересам громадян і суспільству в цілому, захищати ці інтереси та сприяти їх нормальній реалізації. Під функціями Національної поліції України автор розуміє основні напрями їі діяльності, в яких відображено її сутність і призначення в державі та суспільстві в цілому. Водночас реалізація публічно-сервісної функції Національної поліції України полягає у сприянні громадянам у реалізації їхніх прав і законних інтересів, трансформується в публічно-сервісні відносини та забезпечує реалізацію ідеї людиноцентризму у сфері публічного управління [6, с. 18].

На підставі вищенаведеного пропонується виділити такі напрями забезпечення функціонування сектору безпеки і оборони органами та підрозділами Національної поліції:

- боротьба з організованою злочинністю та протидія корупції;

- боротьба з тероризмом;

- протидія незаконній міграції та торгівлі людьми;

- протидія наркоманії, алкоголізму та дитячій безпритульності;

- забезпечення територіальної безпеки.

Сфера боротьби з організованою злочинністю та протидії корупції є одним з головних елементів національної безпеки, функціонування якої забезпечує Національна поліція. 3 точки зору забезпечення національної безпеки організована злочинність - це особливо небезпечна форма злочинної діяльності. Вона постає у вигляді єдиної системи організованих злочинів, між якими існує стійкий взаємозв'язок. Боротьба 3 організованою злочинністю може бути ефективною тільки в разі здійснення їі на міцній законодавчій основі, яка відповідає реальним характеристикам, цілям та завданням сучасного кримінального законодавства.

Наступним напрямом забезпечення функціонування сектору безпеки і оборони органами та підрозділами Національної поліції є боротьба з тероризмом.

У дисертаційному дослідженні В. В. Аброськін зазначає, що «систему суб'єктів забезпечення публічної безпеки в умовах антитерористичної операції утворюють численні правоохоронні органи, завдання яких не завжди безпосередньо пов'язані із забезпеченням публічної безпеки, однак можуть мати 
допоміжний характер. У якості ж суб'єкта, основним призначенням якого $є$ забезпечення публічної безпеки, в тому числі в умовах проведення антитерористичної операції, слід розглядати органи Національної поліції України. Провідна роль вказаного суб'єкта в досліджуваній сфері правовідносин може бути охарактеризована 3 огляду на декілька аспектів, встановлення й аналіз яких передбачає як визначення сутності категорії «суб'єкт забезпечення публічної безпеки», так і використання її по відношенню до органів Національної поліції України в умовах проведення антитерористичної операції» [11, c. 51-52].

Науковці В. Я. Настюк та С. А. Трофімов акцентують увагу на тому, що «подальший розвиток державної політики протидії тероризму нерозривно пов'язаний з підвищенням рівня антитерористичної діяльності органів сектора безпеки, які є суб'єктами різних правовідносин, у тому числі й адміністративно-правових. У зв'язку з цим важливого значення набуває державне управління протидією терористичним загрозам, основними завданнями якого $\epsilon$ виявлення та профілактика тероризму, мінімізація його наслідків» [12].

Таке твердження пояснюється тим, що органи Національної поліції України в умовах проведення антитерористичної операції повсякденно та безперервно виконують завдання, реалізують функції та повноваження, пов'язані із забезпеченням публічної безпеки. На думку В. В. Аброськіна, під органами Національної поліції України як суб'єктом забезпечення публічної безпеки в умовах антитерористичної операції слід розуміти сукупність органів і підрозділів Національної поліції України, які функціонують в умовах антитерористичної операції та залежно від свого функціонального призначення реалізують законодавчо закріплені повноваження, пов'язані із недопущенням і припиненням протиправних посягань, надзвичайних ситуацій природного та техногенного характеру задля підтримання стану захищеності прав свобод та інтересів фізичних і юридичних осіб [11, с. 55].

Закон України «Про боротьбу з тероризмом» закріплюе, що Національна поліція спільно 3 Міністерством внутрішніх справ організовує боротьбу з тероризмом шляхом запобігання, виявлення та припинення злочинів, вчинених з терористичною метою, розслідування яких віднесене законодавством України до її компетенції, а також надає Антитерористичному центру при Службі безпеки України необхідні сили і засоби та забезпечує їх ефективне використання [13].
Додатково законодавець встановив, що сили та засоби (особовий склад та спеціалісти окремих підрозділів, військових частин, зброя, бойова техніка, спеціальні і транспортні засоби, засоби зв'язку, інші матеріально-технічні засоби) Національної поліції України залучаються до широкомасштабних, складних антитерористичних операцій у районі їх проведення за рішенням керівника Антитерористичного центру при Службі безпеки України або особи, яка його заміщує, першого заступника чи заступника керівника Антитерористичного центру при Службі безпеки України, погодженим із керівництвом відповідних суб’єктів боротьби з тероризмом. Керівники територіальних органів Національної поліції входять до складу координаційних груп при регіональних органах Служби безпеки України, а заступники керівника Національної поліції України входять до складу міжвідомчої координаційної комісії Антитерористичного центру при Службі безпеки України [13].

Ще одним важливим напрямом забезпечення функціонування сектору безпеки і оборони органами та підрозділами Національної поліції є протидія незаконній міграції та торгівлі людьми. Цей напрям діяльності покладено на Департамент боротьби зі злочинами, пов'язаними з торгівлею людьми. Він є структурним підрозділом апарату центрального органу управління поліції, який функціонує у складі кримінальної поліції та відповідно до законодавства України забезпечує реалізацію державної політики у сфері протидії торгівлі людьми, запобігання вчиненню, виявлення, припинення та розкриття кримінальних правопорушень, пов'язаних з торгівлею людьми, нелегальною міграцією, правопорушень у сфері суспільної моралі, а також працевлаштування за кордоном [14].

О. А. Болбот зазначає, що збільшення масштабів нелегальної міграції пояснюється кількома факторами: по-перше, обмеженням можливостей легального в'їзду за рахунок посилення імміграційного контролю; по-друге, зростаючим попитом на нелегальних та дешевих іноземних робітників; по-третє, розвитком транспорту і комунікацій, що сприяє контрабанді людьми; по-четверте, скасуванням еміграційного контролю багатьма державами, що мають спільний кордон із західноєвропейськими державами [15, с. 33].

Окрім основних напрямів забезпечення функціонування сектору безпеки і оборони органами та підрозділами Національної поліції, можна виділити додаткові, але також дуже важливі, оскільки вони є підгрунтям для більш вагомих загроз національній безпеці. 
Серед них протидія наркоманії, алкоголізму та дитячій безпритульності.

Національна поліція наділена великим обсягом повноважень у зазначеній сфері.

Як слушно зазначає А. В. Галюк, у сучасних реаліях особливу стурбованість викликає вживання, так би мовити, «легких наркотиків» неповнолітніми та розповсюдження останніх через систему Інтернет, що надалі призводить до систематичного характеру вживання заборонених до обігу наркотиків. Та ситуація, яка склалася в суспільстві щодо розповсюдження наркоманії, потребує негайних заходів реагування як спеціально створених суб'єктів, так і всіх небайдужих до формування здорової нації [10, с. 39].

Як ми бачимо, усі три елементи аналізованого напряму (наркоманія, алкоголізм та дитяча безпритульність) тісно пов'язані між собою та надають можливості взаємного негативного розвитку.

Детальний аналіз Закону України «Про Національну поліцію» та Постанови Кабінету Міністрів України «Про затвердження Положення про Національну поліцію» від 28.10.2015 р. № 877 показує, що на законодавчому рівні не передбачено чіткого закріплення адміністративних повноважень підрозділів Національної поліції України щодо запобігання та протидії наркоманії [8; 16].

Підводячи підсумок, можна навести тези А. В. Галюка про те, що адміністративно-правовий статус Національної поліції України як суб'єкта протидії правопорушенням, які пов'язані із незаконним обігом наркотиків на регіональному рівні, являє собою ієрархічну систему організаційно-функціональних елементів, специфіка яких зумовлена конкретним відособленим призначенням наркотиків місцем і роллю окремих підрозділів поліції у сфері запобігання та протидії наркоманії, характеризується певним обсягом правового інструментарію (компетенції), територіальними межами діяльності (розповсюджується на певний регіон), а також юридичною відповідальністю посадових осіб, які проходять службу в цих органах [10, с. 50].

Щодо протидії алкоголізму та дитячій безпритульності, то ці дві загрози йдуть поряд: де існує алкоголізм, там неодмінно буде дитяча безпритульність, і навпаки.

Основні суб'єкти в структурі Національної поліції, на які покладено відповідні завдання, це підрозділи ювенальної превенції та служба дільничних офіцерів поліції [17; 18].

Як зазначає I. В. Баклан, вони здійснюють попередження наркозлочинності неповнолітніх шляхом: вилучення наркотичних засобів зі сфери їх незаконного обігу, перекриття каналів та джерел їх постачання на територію України; своєчасного реагування на факти схиляння інших осіб до незаконного вживання наркотичних засобів, спільної участі з міжнародними службами у попередженні незаконного наркообігу, розкриття, попередження злочинів у сфері обігу наркотичних засобів та злочинів, що вчинюються у стані наркотичного сп'яніння; систематичного проведення моніторингу наркоситуації, що склалася у державі [19, с. 7].

Відповідно до Стратегії державної політики щодо наркотиків на період до 2020 року, затвердженої розпорядженням Кабінету Міністрів України від 28.08.2013 № 735-р, до основних пріоритетів у діяльності підрозділів Національної поліції, які ведуть боротьбу 3 незаконним обігом наркотиків, належать: забезпечення гласності в діяльності органів Національної поліції з метою підвищення рівня поінформованості населення та розширення соціальної бази протидії наркозлочинності; посилення роботи із забезпечення власної безпеки органів Національної поліції, недопущення втягування співробітників таких органів у наркобізнес, усунення перешкод у боротьбі їх із незаконним обігом наркотиків; зміцнення кадрового потенціалу підрозділів боротьби з незаконним обігом наркотиків шляхом навчання персоналу та підвищення його кваліфікації; забезпечення розвитку адекватних форм інституційного контролю за діяльністю органів Національної поліції у сфері боротьби з незаконним обігом наркотиків насамперед 3 метою дотримання ними законності, прав і свобод людини [20].

I останнім із досліджуваних напрямів забезпечення функціонування сектору безпеки і оборони органами та підрозділами Національної поліції є забезпечення територіальної безпеки.

Участь Національної поліції у забезпечені територіальної безпеки, і територіальної оборони зокрема, носить досить розмитий характер.

Серед основних напрямів здійснення територіальної оборони, які забезпечує поліція, можна виділити: посилення охорони громадського порядку та безпеки громадян; підготовку до боротьби з диверсійно-розвідувальними силами, іншими озброєними формуваннями, антидержавними незаконно утвореними озброєними формуваннями та мародерами; завчасну підготовку у мирний час до охорони та оборони в особливий період важливих об'єктів і комунікацій життєдіяльності; підтримання правового режиму воєнного стану; забезпечення взаємодії суб'єктів територіальної оборони.

Національна поліція сприяе забезпеченню відповідно до закону правового режиму воєнного або надзвичайного стану, 
зони надзвичайної екологічної ситуації у разі їх оголошення на всій території України або в окремій місцевості [8].

Відповідно до Інструкції про порядок взаємодії територіальних органів поліції та міжрегіональних територіальних органів Національної поліції України під час реагування на надзвичайні ситуації у разі введення правового режиму воєнного чи надзвичайного стану, затвердженої наказом МВС України від 31.10.2016 № 1129, відокремлені підрозділи міжрегіональних територіальних органів Національної поліції України в межах своєї компетенції:

1) інформують територіальні органи поліції та їх відокремлені підрозділи (за місцем дислокації) про виявлені ознаки загрози виникнення або повідомляють їм інформацію про реальне виникнення надзвичайних ситуацій та можливі передумови виникнення підстав для виконання спеціальних службових завдань;

2) забезпечують за напрямами діяльності участь в охороні публічного порядку, забезпечують безпеку дорожнього руху, охорону в установленому порядку об'єктів державної, комунальної та приватної власності, протидію злочинності та участь у виконанні завдань територіальної оборони;

3) надають допомогу місцевим органам державної влади, органам місцевого самоврядування, органам військового управління, територіальним органам поліції у проведенні відселення людей з місць, небезпечних для проживання;

4) беруть участь у забезпеченні реалізації спеціального перепускного режиму на межах районів виникнення надзвичайних ситуацій (пожеж, радіоактивного, хімічного, бактеріологічного (біологічного) зараження), районів проведення антитерористичних заходів, а також під час їх ліквідації і супроводження аварійно-рятувальної та іншої спеціальної техніки до осередків зон надзвичайних ситуацій;

5) організовують у межах компетенції регулювання дорожнього руху на маршрутах евакуації, охорону публічного порядку на збірних та приймальних евакуаційних пунктах, пунктах посадки (висадки) на маршрутах евакуації і в районах (пунктах) розміщення евакуйованого населення;

6) планують та здійснюють необхідні заходи щодо захисту життя і здоров'я поліцейських від негативних чинників надзвичайних ситуацій;

7) здійснюють заходи щодо посилення охорони та уведення в дію (за необхідності за окремим наказом) планів оборони адмінбудівель відокремлених підрозділів міжрегіональних територіальних органів Національної поліції України;

8) здійснюють інші заходи, передбачені законодавством України [21].

\section{Висновки}

Таким чином, грунтовний аналіз нормативно-правової бази та теоретичних аспектів досліджуваного питання дав змогу визначити, що забезпечення функціонування сектору безпеки і оборони органами і підрозділами Національної поліції - це законодавчо встановлений комплекс заходів правового, організаційного та фінансового характеру, який спрямований на виконання завдань та функцій щодо захисту державного суверенітету, територіальної цілісності і демократичного конституційного ладу та інших життєво важливих національних інтересів від реальних і потенційних загроз невоєнного характеру органами та підрозділами Національної поліції.

Під напрямками забезпечення функціонування сектору безпеки і оборони органами і підрозділами Національної поліції пропонується розуміти систему пріоритетних завдань та функцій Національної поліції у сфері охорони національної безпеки.

Основні напрями забезпечення функціонування сектору безпеки і оборони органами та підрозділами Національної поліції базуються на відповідних завданнях вказаного сектору. На підставі вищенаведеного пропонується виділити такі напрями: боротьба з організованою злочинністю та протидія корупції; боротьба з тероризмом; протидія незаконній міграції та торгівлі людьми; протидія наркоманії, алкоголізму та дитячій безпритульності; забезпечення територіальної безпеки.

\section{Список використаних джерел:}

1. Про національну безпеку України : Закон України від 21 червня 2018 р. № 2469-VIII / Верховна Рада України. Відомості Верховної Ради України. 2018. № 31. Ст. 241.

2. Про рішення Ради національної безпеки і оборони України від 4 березня 2016 року «Про Концепцію розвитку сектору безпеки і оборони України» : Указ Президента України від 14 березня 2016 р. № 92/2016 // База даних «Законодавство України». URL: https://zakon.rada.gov.ua/laws/ show/92/2016 (дата звернення: 10.03.2020).

3. Платонов С.В. Искусство управленческой деятельности. Киев : Либра, 1996. 413 с.

4. Адміністративне право України. Академічний курс : підручник : у 2 т. / редкол.: В.Б. Авер'янов (голова) та ін. Київ: Юрид. думка, 2007. Т. 1: Загальна частина. 592 с.

5. Бандурка O.M. Теорія і практика управління органами внутрішніх справ України : монографія. Харків : ХНУВС, 2004. 780 с.

6. Троян В.А. Завдання та функції Національної поліції України як складова реалізації ії публічно-сервісної діяльності. Вісник Харківського начіонального університету внутрішніх справ. 2016. № 4 (75). C. 12-18. 
7. Амельчакова В.Н. Административно-правовое регулирование деятельности органов внутренних дел по обеспечению национальной безопасности в Российской Федерации : дисс. ... канд. юрид. наук : 12.00.14. Москва, 2006. 240 с.

8. Про Національну поліцію : Закон України від 2 липня 2015 р. № 580-VIII. Відомості Верховної Ради Украӥни. 2015. № № 40-41. Ст. 379.

9. Кулик Я.О. Основні напрямки діяльності національної поліції України. Україна і світ: гуманітарно-технічна еліта та соціальний прогрес. До 55 річниціпершого польотулюдиниукосмос:тези доп. Міжнар. наук.-теор. конф. студ. і аспір., 19-20 квітня 2016 р., м. Харків : у 3 ч. Ч. 2 / редкол. С.І. Сокол [та ін.]. Харків : НТУ "ХПІ", 2016. С. 205-206.

10. Галюк А.В. Адміністративно-правові засади діяльності Національної поліції України щодо запобігання та протидії наркоманії на регіональному рівні : дис. ... канд. юрид. наук : 12.00.07. Харків, 2019. 233 c

11. Аброськін В.В. Адміністративно-правові засади забезпечення Національною поліцією України публічної безпеки в умовах проведення антитерористичної операції : дис. ... канд. юрид. наук : 12.00.07. Харків, 2018. 238 с

12. Настюк В.Я., Трофімов С.А. Адміністративно-правове забезпечення державної політики протидії тероризму: доктринальні підходи. URL: http://dspace.nlu.edu.ua/bitstream/ 123456789/7174/1/Nastyk_Trofimov_214.pdf (дата звернення: 11.03.2020)

13. Про боротьбу з тероризмом : Закон України від 20 березня 2003 р. № 638-IV. Відомості Верховної Ради Украӥни. 2003. № 25. Ст. 180.

14. Положення про Департамент боротьби зі злочинами, пов'язаними 3 торгівлею людьми, Національної поліції України : наказ Національної поліції від 19 грудня 2017 р. № 1307. Офіиійнии сайт Національної поліиї. URL: https:// www.npu.gov.ua/about/struktura/struktura/dbzptl. html (дата звернення: 10.03.2020).
15. Болбот О.А. Миграция населения в контексте проблем национальной безопасности. Национальная безопасность России: проблемь и пути обеспечения. Москва, 2003. С. 31-41.

16. Про затвердження Положення про Національну поліцію : Постанова Кабінету Міністрів України від 28 жовтня 2015 р. № 877. URL: https://zakon.rada.gov.ua/laws/show/877-2015\%D0\%BF (дата звернення: 11.03.2020).

17. Про затвердження Інструкції з організації діяльності дільничних офіцерів поліції : наказ MBC України від 28 липня 2017 р. № 650. URL: http://zakon.rada.gov.ua/go/z1041-17 (дата звернення: 10.03.2020)

18. Про затвердження Інструкції з організації роботи підрозділів ювенальної превенції Національної поліції України : наказ МВС України від 19 грудня 2017 р. № 1044. URL: https:// zakon.rada.gov.ua/go/z0686-18 (дата звернення: 18.03.2020).

19. Баклан I.В. Кримінологічна характеристика та попередження злочинів у сфері обігу наркотичних засобів, психотропних речовин, їх аналогів або прекурсорів, що вчинюються неповнолітніми : автореф. дис. ... канд. юрид. наук: 12.00.08. Київ, 2007. 22 с.

20. ПросхваленняСтратегіїдержавноїполітики щодо наркотиків на період до 2020 року : розпорядження Кабінету Міністрів України від 28 серпня 2013 p. № 735-p. URL: https://zakon.rada.gov.ua/ laws/show/735-2013-\%D1\%80 (дата звернення: 18.03.2020)

21. Про затвердження Інструкції про порядок взаємодії територіальних органів поліції та міжрегіональних територіальних органів Національної поліції України під час реагування на надзвичайні ситуації, у випадку уведення правового режиму воєнного чи надзвичайного стану : наказ МВС України від 31 жовтня 2016 р. № 1129 URL: https://zakon.rada.gov.ua/laws/ show/z0085-17 (дата звернення: 18.03.2020).

The purpose of the article is to identify and characterize the priority areas for ensuring the functioning of the security and defense sector by the bodies and units of the National Police. The article shows that the main directions of ensuring the functioning of the security and defense sector by the bodies and units of the National Police are based on the relevant tasks of the specified sector. The key areas for ensuring the functioning of the security and defense sector by the bodies and units of the National Police have been identified and analyzed: the fight against organized crime and the fight against corruption; the fight against terrorism; counteracting illegal migration and human trafficking; combating drug addiction, alcoholism and child homelessness; ensuring territorial security. It was emphasized that under the directions of ensuring the functioning of the security and defense sector the bodies and units of the National Police are offered to understand the system of priorities and functions of the National Police in the field of national security. It has been determined that ensuring the functioning of the security and defense sector by the bodies and units of the National Police is a legally established set of legal, organizational and financial measures aimed at fulfilling the tasks and functions of protecting state sovereignty, territorial integrity and democratic constitutional order and other vital national structures interests from real and potential threats of a nonmilitary nature by the bodies and units of the National Police. Among the main areas of territorial defense provided by the police are the following: strengthening the protection of public order and security of citizens; preparation for the fight against sabotage forces, other armed forces, anti-state illegally formed armed units and looters; early preparation in peacetime for protection and defense in a special period of important objects and communications of vital activity; maintaining the legal regime of martial law; ensuring the interaction of territorial defense entities.

Key words: National police, security and defense sector, directions, tasks, interaction. 